\title{
Isolation and Characterization of SDS (Sodium Dodecyl Sulfate) Degrading Organisms from SDS Contaminated Areas
}

\author{
J. Usharani ${ }^{1}$, T. Rajasekar ${ }^{1 *}$ and B. Deivasigamani² \\ ${ }^{1}$ Sri Sankara Arts and Science College, Enathur, Kanchipuram, Tamil Nadu, India \\ ${ }^{2}$ Faculty of Marine Sciences, CAS Marine Biology, Annamalai University, Parangipettai, Tamil Nadu, India
}

\begin{abstract}
Due to widespread use of Sodium Dodecyl Sulfate (SDS) in households and industry followed by its subsequent disposal in waterways, there is apprehension of alarming consequences on various living organisms. In order to design effective bioremediation strategy in the tropics, efficient strains having fast degradation capacity and high optimum growth temperature are much needed. Biodegradation is the process whereby organic (i.e. carboncontaining) matter is decomposed by the action of microorganisms present in the environment. In the present investigation, a new method for isolation, selective screening optimization of SDS degrading organisms from different SDS contaminated soil. We report here the isolation of bacteria capable of SDS biodegrading by enrichment culturing from SDS contaminated soil. Totally 40 strains were isolated from enrichment media by using Basal medium. Based on the primary screening 40 bacterial strains, 4 bacterial strains were shown better zone of clearances which it taken for MBAS assay. Finally HS 18 showed an $80 \%, 53 \%, 24 \%$, and 23\% degrading activity in $1 \mathrm{~g}, 2 \mathrm{~g}, 3 \mathrm{~g}$ and $4 \mathrm{~g}$ of $\mathrm{SDS}$ in $100 \mathrm{ml}$ respectively than other bacteria.
\end{abstract}

Keywords: Biodegradation; Surfactants; SDS; MBAS assay; Pseudomonas $s p$

\section{Introduction}

Surfactants are synthetic organic chemicals that are formulated to have cleansing or solubilisation properties with the development of the industrial economy and increase in population density, surfactants have become one of the most widely disseminated xenobiotics to enter the aquatic environment, creating a serious environmental problem. Principal criterion for the ecological behavior of surfactants is their biodegradability [1]. Anionic surfactants are groups of xenobiotic compounds that contain either sulfonated or ester sulfate groups [2] which are widely used ingredients in several industrial products such as detergents and cosmetics [3]. Because of their large consumption worldwide, anionic surfactants have the potential for wide disposal in to aquatic and terrestrial environments [4]

Anionic surfactants are present in monomeric form in both apolar and polar solvents at low concentration. At a higher concentration (Critical Micelle Concentration- CMC), they form regular aggregates polarity of the solvent, on the structural characteristics of the surfactant molecule [5,6] and on the ion concentration of the solution [7]. Use of detergents containing synthetic surfactants that commonly possess strongly anionic groups such as sulfonate $\left(\mathrm{C}_{-} \mathrm{So}_{3}-\right)$ or ester sulfate $\left.\mathrm{C}-\mathrm{O}-\mathrm{So}_{3}{ }^{-}\right)$has increased dramatically, in terms of volume and range of applications [1], since their introduction on a commercial scale over 40 years ago. At the concentrations used, the surfactants did not affect bacterial growth, so that toxicity was eliminated as the mode of action in favour of disruption of hydrophobic interactions more recently, the cationic surfactant cetyl pyridinium chloride was shown to enhance microbial adhesion to hexadecane by diminishing surface charge and increasing cell surface hydrophobicity [8].

One of the major xenobiotic anionic surfactants that have large scale industrial applications and thus wide environmental release is Sodium Dodecyl Sulphate (SDS); it is mainly used in industrial cleaners and household detergents. It is also widely used in other industries as emulsifiers, dissertators, synergists in the pharmaceutical field, as auxiliaries in textile and fibre production as well as in the plastic, paint, leather, photographic and metal industries [9]. This surfactant is mostly discarded through domestic or industrial waste water. Surfactants, due to their favorable physicochemical properties are extensively used in many fields of technology and research i.e in pharmacy, in cosmetics, textile industry, agriculture, biotechnology. The use large quantities of surfactants and their derivatives are released to aquatic and or terrestrial environment. These compounds can act on biological wastewater treatment processes and cause problems in sewage aeration and treatment facilities due to their high foaming, lower oxygenation potentials and making death of waterborne organisms [10].

Biodegradation wasinitiated by primary or secondaryalkyl sulfatases enzymes, followed by the oxidation of the liberated primary or secondary alcohols by appropriate alcohol dehydrogenases. Pseudomonas sp are capable of producing a multiplicity of alkyl sulfatases. Pseudomonas can produce five such enzymes [11], Pseudomonas putida FLA six [12] and Pseudomonas DESI four [13] of the five alkyl sulfatases produced by Pseudomonas C12B, two (designated PI and PII) are active towards primary alkyl sulfates, where as the other three (S1, S2 and S3) act on secondary alkyl sulfates [14]. The latter enzyme exhibits positional and Stero-specificity, S1 being active towards D-2-alkyl sulfates, S2 towards symmetrical and near symmetrical secondary alkyl sulfates. Interestingly, now there are reports of several bacteria, which are able to degrade and metabolize SDS as a carbon source. The work on SDS biodegradation was first initiated by Payne and Feisal (1963). They did a detailed study on SDS biodegradation by Pseudomonas sp, including enzymes and kinetics of degradation. Biodegradation of SDS was

${ }^{*}$ Corresponding author: T. Rajasekar, M.Phil, Sri Sankara Arts and Science College, Enathur, Kanchipuram- 631 502, Tamil Nadu, India, Tel: 9751236647 ; E-mail: microraja09@gmail.com

Received July 21, 2012; Published July 20, 2012

Citation: Usharani J, Rajasekar T, Deivasigamani B (2012) Isolation and Characterization of SDS (Sodium Dodecyl Sulfate) Degrading Organisms from SDS Contaminated Areas. 1: 148. doi:10.4172/scientificreports.148

Copyright: (c) 2012 Usharani J, et al. This is an open-access article distributed under the terms of the Creative Commons Attribution License, which permits unrestricted use, distribution, and reproduction in any medium, provided the original author and source are credited. 
Citation: Usharani J, Rajasekar T, Deivasigamani B (2012) Isolation and Characterization of SDS (Sodium Dodecyl Sulfate) Degrading Organisms from SDS Contaminated Areas. 1: 148. doi:10.4172/scientificreports. 148

Page 2 of 4

also reported by consortia of Acinetobacter calcoaceticus and Pantoea agglomerans. Notably biodegradation of SDS by facultative anaerobic bacteria is rare occurrence [15]. Several authors have investigated the effects of surfactants on the adhesion of bacteria at water-oil and water-solid interfaces. In the present study was attempted to study the isolation, characterization and degradation of Sodium Dodecyl Sulphate by bacteria from detergent contaminated soil from different environmental samples. And also study the SDS degrading by using MBAS.

\section{Materials and Methods}

\section{Collection sample}

In this present study the isolation of SDS degrading bacteria from detergent contaminating soil. The samples were collected from in and around Kanchipuram. The samples were collected in a sterile polythene bag with wetness sealed and transfer to laboratory.

\section{Enrichment of sample}

The five gram of soil sample was taken and added to the flask containing $500 \mathrm{ml}$ of basal medium (consisting of $1 \mathrm{gram} / 100 \mathrm{ml}$ of SDS) for enrichment of bacteria. The conical flask was kept in shaker for incubation at $28^{\circ} \mathrm{C}$ for " $24 \mathrm{~h}$ " [16].

\section{Enumeration and isolation of organisms}

The enriched samples were taken for the isolation of bacteria. 0.1 $\mathrm{ml}$ of enrichment sample was spread on to basal medium agar plate containing (consisting of 1 gram per $100 \mathrm{ml}$ ) SDS as the only source of carbon energy. The plate was incubated at $28^{\circ} \mathrm{C}$ [16]. The incubated plates were observed for SDS degrading bacteria. The morphologically different colony was selected and streaked on fresh nutrient agar plate and incubated at $28^{\circ} \mathrm{C}$ for " $24 \mathrm{~h}$ ". All the strains were preserved at $4^{\circ} \mathrm{C}$ until further studies.

\section{Screening for SDS degrading bacteria}

All the selected bacterial strains were further screened for confirmation of SDS degrading activity. The bacterial strains were spotted on Bacto agar incorporated with (consisting of 1 gram per 100 $\mathrm{ml}$ ) SDS. The plates were incubated at $28^{\circ} \mathrm{C}$ for " $24 \mathrm{~h}$ ". After incubation, the plate were flooded with Lugol's iodine and observed for the zone of clearance around the bacterial growth. Strain which showed maximum zone of clearance on their preliminary screening that selected potential strain used for further studies.

\section{SDS degradation study by Methylene Blue Active Substance (MBAS) assay}

The concentration of residual SDS was determined by measuring the intensity of Methylene blue in a chloroform extraction process [17]. All the strains were inoculated with Basal medium and incubated at $28^{\circ} \mathrm{C}$ for " $24 \mathrm{~h}$ ". After incubation all the samples were studied for SDS degradation by using MBAS assay. Each $100 \mu \mathrm{l}$ of culture were added in to the separated $100 \mathrm{ml}$ of separating funnel containing 9.9 $\mathrm{ml}$ deionized water followed by the addition of $2.5 \mathrm{ml}$ Methylene blue solution and $1 \mathrm{ml}$ of chloroform. The funnel was shaken vigorously for $15 \mathrm{sec}$ and the mixture was left to separate and settle. The chloroform layer was drawn off in to a second funnel. The extraction was repeated 3 times using $1 \mathrm{ml}$ chloroform each time. All chloroform extracts were combined in the second funnel before adding $5.0 \mathrm{ml}$ of wash solution. The funnel was then shaken vigorously for $15 \mathrm{sec}$. The chloroform layer was drawn off in to a volumetric flask. The wash solution was extracted twice with $1 \mathrm{ml}$ of chloroform. All extracts were combined and diluted to the $10 \mathrm{ml}$ mark with chloroform. The absorbance was read at $652 \mathrm{~nm}$ against blank chloroform in a quartz cuvette.

\section{Characterization and identification of potential strain}

Microscopic observation, cultural, biochemical and selective media characteristic of potential SDS degrading strain was studied by adopting standard procedure and the potential strain was identified by using Bergey's Mannual of systematic bacteriology.

\section{Results}

\section{Enumeration and isolation of organism}

Twenty, Five and Fifteen number of individual colonies were isolated from Home Samples (HS), Temple Samples (TS) and Lake Sample (LS) respectively. The total 40 strains were isolated from three sample area. All the strains were maintained in Nutrient agar slant.

\section{Primary screening of SDS degrading bacteria}

Screening of SDS degrading bacteria was screened by using Bacto

\begin{tabular}{|c|c|c|c|c|c|}
\hline S. No & Strain no & Zone of clearance & S. No & Strain no & Zone of clearance \\
\hline 1 & HW1 & - & 21 & TS21 & - \\
\hline 2 & HW2 & - & 22 & TS22 & - \\
\hline 3 & HW3 & - & 23 & TS23 & - \\
\hline 4 & HW4 & - & 24 & TS24 & - \\
\hline 5 & HW5 & - & 25 & TS25 & - \\
\hline 6 & HW6 & - & 26 & LW26 & + \\
\hline 7 & HW7 & - & 27 & LW27 & - \\
\hline 8 & HW8 & - & 28 & LW28 & + \\
\hline 9 & HW9 & - & 29 & LW29 & - \\
\hline 10 & HW10 & - & 30 & LW30 & - \\
\hline 11 & HW11 & - & 31 & LW31 & - \\
\hline 12 & HW12 & + & 32 & LW32 & - \\
\hline 13 & HW13 & - & 33 & LW33 & - \\
\hline 14 & HW14 & - & 34 & LW34 & - \\
\hline 15 & HS15 & - & 35 & LW35 & - \\
\hline 16 & HS16 & - & 36 & LW36 & - \\
\hline 17 & HS17 & - & 37 & LW37 & - \\
\hline 18 & HS18 & ++ & 38 & LW38 & + \\
\hline 19 & HS19 & - & 39 & LW39 & - \\
\hline 20 & HS20 & + & 40 & LW40 & + \\
\hline
\end{tabular}

Table 1: Preliminary Screening of SDS degradation

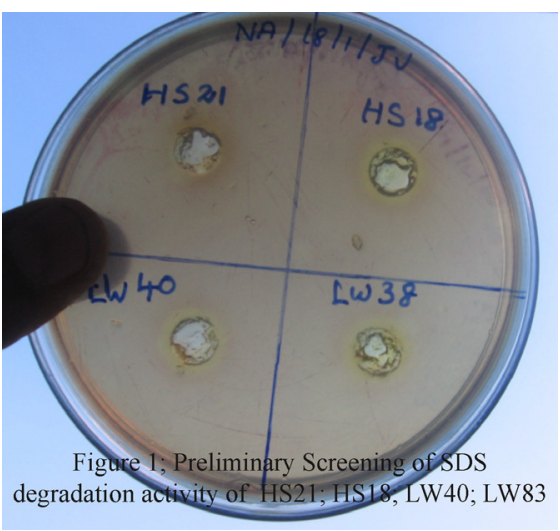

Figure 1: Preliminary screening of SDS degradation activity of HS21; HS18; LW40; LW83. 
Agar (incorporated with 1 gram per of SDS $100 \mathrm{ml}$ ). Totally 40 bacteria were studied for the degrading activity (Table 1). Among the 40 strains 4 strains showed zone of clearance around the well. The best degrading activity of all the 4 strains was given in the Figure 1. Hence 4 strains selected for MBAS assay.

\section{Selection of potent strain by Methylene Blue Active Substance (MBAS) assay}

HS18 showed $80 \%, 53 \%, 24 \%$, and $23 \%$, HS21 showed a $30 \%$, $10 \%, 17 \%$ and $18 \%$, LW 38 showed $20 \%, 20 \%, 07 \%$ and $13 \%$ and LW 40 showed a $50 \%, 15 \%, 10 \%$, and $10 \%$ of degradation activity in $1 \mathrm{~g}, 2 \mathrm{~g}, 3$ $\mathrm{g}$ and $4 \mathrm{~g}$ in $100 \mathrm{ml}$ of SDS respectively. The MBAS assay results of all the 4 strains was given in Figure 2. Based on the MBAS assay out of four strains, one strains (HS18) showed a better degradation activity. Hence the HS18 were selected for the identification studies.

\section{Characterizatation and identification of potential strain}

Microscopic observation, cultural and biochemical characteristic of potential SDS degrading strain was studied by adopting standard procedure and the potential strain was identified by Bergey's Mannual of systematic bacteriology (Table 2). Based on the biochemical analysis the organisms identified as a Pseudomonas sp (Figure 3)

\section{Disscussion}

Due to their amphiphilic properties, long-chain aliphatic sulfate esters such as Sodium Dodecyl Sulfate (SDS) are widely used

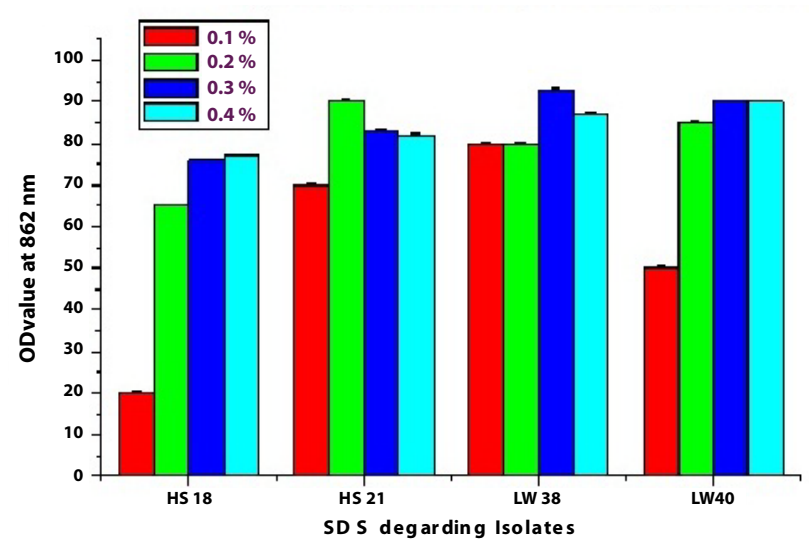

Figure 2: Degradation study of SDS by MBAS assay.

\begin{tabular}{|c|c|c|c|}
\hline S.NO. & Characterization & Manual Result* & Result \\
\hline 1 & $\begin{array}{c}\text { Gram Staining and } \\
\text { shape }\end{array}$ & $\begin{array}{c}\text { Gram Negative and } \\
\text { rods }\end{array}$ & $\begin{array}{c}\text { Gram Negative and } \\
\text { rods }\end{array}$ \\
\hline 2 & Motility & Motile & Motile \\
\hline 3 & Catalase & Positive & Positive \\
\hline 4 & Oxidase & Positive & Positive \\
\hline 5 & Indole & Negative & Negative \\
\hline 6 & Methyl red & Negative & Negative \\
\hline 7 & Vogus Proskauer & Negative & Negative \\
\hline 8 & Citrate & Positive & Positive \\
\hline Cultural characterization & & White color colonies was observed \\
\hline 1 & Nutrient Agar & Growth was observed, Non pigmented \\
\hline 2 & Cetrimide Agar & \multicolumn{2}{|c}{} \\
\hline
\end{tabular}

*Bergey's Mannual

Table 2: Characterization of isolated organisms.

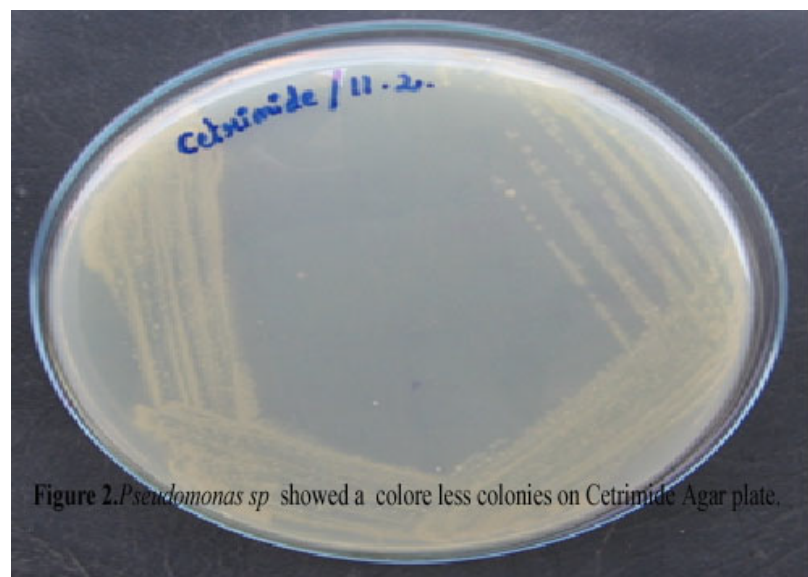

Figure 3: Psuedomonas sp showed colorless colonies on Centrimide Aga plate.

as components of surfactant formulations and are consequently discharged into wastewater. It is realized that rapid removal of surfactants from the environment will make their application safer and widespread. Using microorganisms to degrade surfactants is one promising method [18]. In the present study, we have made an attempt to isolate SDS degrading bacteria from detergent polluted area situated in Kanchipuram, India. These areas where used extensively for washing of clothes and also for bathing purposes. In this study, we have screened three areas like Home waste, Pond and Lack situated in different parts of Kanchipuram town.

Past experiences have demonstrated that anionic surfactants biodegradation are exclusively conducted by bacteria [19]. Using enrichment technique in minimal medium, Chaturvedi and Kumar [20] isolated 6 SDS degrading bacteria from two detergent contaminated ponds. The kinetics of degradation of SDS by these isolates was studied by monitoring disappearance of SDS with time and also by measuring the growth of the isolate. It was observed that these isolates showed varying rates of SDS biodegradation. Only two isolates namely JN1 and PM2 showed appreciable level of biodegradation. This present study also using the minimal medium, for the isolation of 40 SDS degrading bacteria from three detergents contaminated area. Based on the screening for SDS degrading, only 4 bacteria showed activity in $1 \mathrm{~g}$ in $100 \mathrm{ml}$ of SDS containing bactoagar plates.

Hyashi et al. [21] have used Methylene Blue Activated Substances (MBAS) method for determination of anionic surfactant biodegradation in aquatic environments. Schulz et al. [4] have suggested that the presence of contaminating ions and intermediate compounds can inhibit precise detection of SDS levels by the Methylene-Blue assay. They suggested that HPLC is a superior technique for SDS identification. This indicates that the bacteria are actually utilizing SDS as their sole carbon source. This is in agreement with the results of other investigators [22,23]. In this present study SDS degradation work was carried out and SDS was measured by MBAS assay. HS18 showed $80 \%, 53 \%, 24 \%$ and $23 \%$, HS 21 showed a $30 \%, 10 \%, 17 \%$ and $18 \%$, LW38 showed a $20 \%, 20 \%, 07 \%$ and $13 \%$ and LW40 showed a $50 \%, 15 \%, 10 \%$ and $10 \%$ of degradation activity in $1 \mathrm{~g}, 2 \mathrm{~g}, 3 \mathrm{~g}$ and $4 \mathrm{~g}$ in $100 \mathrm{ml}$ of SDS respectively. Totally four out of one (HS18) organism showed well degrading activity in $1 \mathrm{~g}, 2 \mathrm{~g}, 3 \mathrm{~g}$ and $4 \mathrm{~g}$ in $100 \mathrm{ml}$ of SDS.

Based on the phenotypic characteristics the potential strain was identified as Pseudomonas sp (HS18). The obtained results has shown 
Citation: Usharani J, Rajasekar T, Deivasigamani B (2012) Isolation and Characterization of SDS (Sodium Dodecyl Sulfate) Degrading Organisms from SDS Contaminated Areas. 1: 148. doi:10.4172/scientificreports. 148

that anionic surfactants significantly biodegraded by bacteria.

\section{Conclusion}

The obtained results concluded that anionic surfactants significantly biodegraded by bacteria. The results of this study suggest that growth of simple bacteria in household and industrial sewage can be a costeffective method of anionic surfactant elimination. In conclusion, we have isolated an SDS-degrading bacterium from an SDS-polluted water sample from Kanchipuram. HS18 showed $80 \%, 53 \%, 24 \%$, and $23 \%$ of degrading activity in $1 \mathrm{~g}, 2 \mathrm{~g}, 3 \mathrm{~g}$ and $4 \mathrm{~g}$ of SDS in $100 \mathrm{ml}$ respectively. The relatively high optimum temperature for growth on SDS exhibited by this bacterium is suitable to be used for the bioremediation of SDS polluted sites in Kanchipuram. Based on the phenotypic characteristics the potential strain was identified as Pseudomonas sp (HS18). The results of this study suggest that growth of simple bacteria such as Pseudomonas sp in household and industrial sewage can be a costeffective method of anionic surfactant elimination.

\section{Acknowledgement}

The authors would like to express heartfelt thanks to the Principal, Sri Sankara Arts and Science College, Kanchipuram, Tamil Nadu, India for providing lab facilities.

\section{References}

1. Bin Syed MA, Abdul Shukor MYB, Shamaan NA (2010) Isolation and characterization of SDS-degrading Pseudomonas aeruginosa sp. Strain D1. Aust J Basic Appl Sci 4: 5000-5011.

2. Karsa DR (Ed.) (1987) Industrial Applications of Surfactants (Special Publication No. 59), Royal Society of Chemistry, London.

3. Swisher RD (1987) Surfactant Biodegradation, Marcel Dekker Inc., New York, USA 18.

4. Schulz S, Dong W, Groth U, Cook AM (2000) Enantiomeric degradation of 2-(4-Sulfophenyl) Butyrate via 4-sulfocatechol in Delftia acidovorans SPB1. Appl Environ Microbiol 66: 1905-1910.

5. Schleheck D, Dong W, Denger K, Heinzle E, Cook AM (2000) An alphaproteobacterium converts linear alkylbenzenesulfonate surfactants into sulfophenylcarboxylates and linear alkyldiphenyletherdisulfonate surfactants into sulfodiphenylethercarboxylates. Appl Environ Microbiol 66: 1911-1916.

6. Okano T, Tamura T, Nakano TY, Ueda SI, Lee S, et al. (2000) Effect of side chain length and degree of counterion binding on micellization of sodium salts

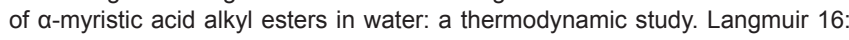
3777-3783

7. Jalali-Heravi M, Konouz E (2000) Prediction of critical micelle concentration of some anionic surfactants using multiple regression techniques. A quantitative structure- activity relationship study. J Surfactants Deterg 3: 47-52.
8. Talens-Alesson FI (1999) Behaviour of anionic surfactant micelles in the presence of $\mathrm{Al}^{3+}$ and $\mathrm{Ca}^{2+}$. J Dispers Sci Technol 20: 1861- 1871

9. Goldberg S, Konis Y, Rosenberg M (1990) Effect of cetylpyridinium chloride on microbial adhesion to hexadecane and polystyrene. Appl Environ Microbiol 56: $1678-1682$.

10. Falbe J (1987) Surfactants in Consumer Products. Theory, Technology and Application, New York, London 547.

11. Eichhorn P, Rodrigues SV, Baumann W, Knepper TP (2002) Incomplete degradation of linear alkylbenzene sulfonate surfactants in Brazilian surface waters and pursuit of their polar metabolites in drinking waters. Sci Total Environ 284: 123-134.

12. Bateman TJ, Dodgson KS, White GF (1986) Primary alkylsulphatase activities of the detergent-degrading bacterium Pseudomonas C12B. Purification and properties of the P1 enzyme. Biochem J 236: 401-408.

13. Lillis V, Dodgson KS, White GF, Payne WJ (1983) Initiation of activation of a preemergent herbicide by a novel alkylsulfatase of Pseudomonas putida FLA Appl Environ Microbiol 46: 988-994.

14. Matcham GWJ (1977) Stereospecificity and complexity of microbia sulfohydrolases involved in the biodegradation of secondary aklylsulfate detergents. FEMS Microbiol Lett 1: 197-200.

15. Cloves M, Dodgson KS, White GF, Fitzgerald JW (1980) Purification and properties of the $\mathrm{P} 2$ primary alkylsulphohydrolase of the detergent-degrading bacterium Pseudomonas C12B. Biochem J 185: 23-31.

16. Abboud MM, Khleifat KM, Batarseh M, Tarawneh KA, Al-Mustafa A, et al. (2007) Different optimization conditions required for enhancing the biodegradation of linear alkylbenzosulfonate and sodium dodecyl sulfate surfactants by novel consortium of Acinetobacter calcoaceticus and Pantoea agglomerans. Enzyme Microbial Technol 41: 432-439.

17. Shukor MY, Husin WS, Rahman MF, Shamaan NA, Syed MA (2009) Isolation and characterization of an SDS-degrading Klebsiella oxytoca. J Environ Biol 30: 129-134.

18. Zeng G, Fu H, Zhong H, Yuan X, Fu M, et al. (2007) Co-degradation with glucose of four surfactants, CTAB, Triton X-100, SDS and Rhamnolipid in liquid culture media and compost matrix. Biodegradation 18: 303-310.

19. Di Corcia A, Samperi A, Marcomini A (1994) Monitoring aromatic surfactants and their biodegradation intermediates in raw and treated sewages by solidphase extraction and liquid chromatography. Environ Sci Technol 28: 850-858.

20. Chaturvedi V, Kumar A (2010)A simple staining method for increasing sensitivity in detection of alkyl sulfatase in native Polyacrylamide gels. J Phytol 2: 34-36.

21. Hayashi K (1975) A rapid determination of sodium dodecyl sulfate with methylene blue. Anal Biochem 67: 503-506.

22. Jimenez L, Breen A, Thomas N, Federle TW, Sayler GS (1991) Mineralization of linear alkylbenzene sulfonate by a four-member aerobic bacterial consortium. Appl Environ Microbiol 57: 1566-1569.

23. Sigoillot JC, Nguyen MH (1992) Complete oxidation of linear alkylbenzene sulfonate by bacterial communities selected from coastal seawater. App Environ Microbiol 58: 1308-1312. 